Dariusz Drążkowski

Lidia Cierpiałkowska

Instytut Psychologii

Uniwersytet im. Adama Mickiewicza

w Poznaniu

\author{
Psychologia Jakości Życia \\ Psychology of Quality of Life \\ 2013, tom 12 , nr 1 (29-41) \\ DOI: $10.5604 / 16441796.1088798$
}

\title{
Zależność/niezależność od pola a wsparcie społeczne w kontekście stresu
}

\begin{abstract}
Artykuł prezentuje wyniki badania, którego celem była analiza związków między zależnością/niezależnością od pola a wymiarami wsparcia społecznego w kontekście stresu. Zbadano 85 osób w wieku 19-58 lat $(M=36,4 ; S D=10,66)$ za pomocą Berlińskich Skal Wsparcia Spolecznego (BSSS), Skali Odczuwanego Stresu (PSS-10) oraz Testu Ukrytych Figur Witkina (GEFT). Wyniki pokazują, że istnieje ujemna niska korelacja pomiędzy niezależnym od pola stylem poznawczym i poszukiwanym wsparciem społecznym $(r=-0,29)$. Nie wykryto istotnych związków niezależności od pola ze spostrzeganym i otrzymywanym wsparciem społecznym. Natomiast uzyskano interakcję zależności/niezależności od pola ze spostrzeganym wsparciem społecznym dla poziomu stresu $\left(f^{8}=13,3\right)$.
\end{abstract}

Slowa kluczowe: zależność/niezależność od pola, wsparcie społeczne, stres, styl poznawczy

\section{Wprowadzenie}

\section{Transakcyjna koncepcja stresu}

Stres w transakcyjnej teorii stresu definiuje się jako taką relację osoby z otoczeniem, którą ocenia ona jako obciążającą lub przekraczającą jej zasoby i zagrażającą jej dobrostanowi (Lazarus i Folkman, 1984). W tym klasycznym modelu rozróżnia się ocenę pierwotną i wtórną stresu. W trakcie pierwotnej oceny stresu osoba spostrzega wymagania stresującej sytuacji i podejmuje decyzję, czy stanowią one dla niej stratę, zagrożenie, wyzwanie czy zysk. Natomiast oce-

Adres do korespondencji:

Dariusz Drążkowski, Instytut Psychologii UAM, ul. Szamarzewskiego 89, Poznań 60-568,

tel.: (48 61) 82923 07, fax: (48 61) 82921 07; email: darekraciazek@onet.eu,

Lidia Cierpialkowska: email: lcierp@amu.edu.pl 
na wtórna dotyczy zarówno oceny źródeł stresu, jak i spostrzeganych zasobów, które umożliwiają sprostanie wymaganiom otoczenia. Dynamicznie zmieniająca się ocena wtórna pozwala na dokonywanie wyboru poznawczych i behawioralnych wysiłków skierowanych na przezwyciężenie stresu, co nazywane jest radzeniem sobie ze stresem (Lazarus i Folkman, 1987).

Do spostrzeganych zasobów środowiskowych, które wplywają na ocenę sytuacji jako stresującej, przynależy wsparcie społeczne (Lazarus, DeLongis, Folkman i Gruen, 1985). Z kolei poszukiwane wsparcie społeczne jest uznawane za strategię radzenia sobie ze stresem, co znajduje potwierdzenie w klasyfikacjach sposobów radzenia sobie takich autorów, jak Carver, Hobfoll czy Moos (Łosiak, 2008). Wsparcie społeczne może być także rozpatrywane jako moderator między stresem a jego psychologicznymi konsekwencjami (Frese, 1999), mediator między strategią radzenia sobie a poziomem stresu i/lub jako modyfikator poznawczej oceny sytuacji (Łosiak, 2008). Wsparcie społeczne spełnia zatem bardzo złożone funkcje w transakcji stresowej.

\section{Wsparcie społeczne}

Wsparcie społeczne przyjęło się definiować na dwa sposoby, podkreślając jego strukturalny albo funkcjonalny charakter (Sęk i Cieślak, 2004). W podejściu strukturalnym wsparcie spoleczne określa się przez stopień uczestnictwa jednostki w sieci społecznej, co sprowadza się do wskazywania na poziom jej integracji z tą siecią (Cohen, Gottlieb i Underwood, 2000). W podejściu funkcjonalnym badacze koncentrują się na wyjaśnieniu funkcji, jaką pełni interakcja wspierająca w relacji pomiędzy jednostką a jej siecią kontaktów interpersonalnych (Kasperczyk, 2006). Tak rozumiane wsparcie ujmuje się jako rodzaj interakcji społecznej, zainicjowanej w sytuacji stresu w celu osłabienia tegoż stresu (Sęk, 1985; Sęk i Cieślak, 2004).

Funkcjonalne podejście do wsparcia pozwala na wyodrębnienie różnych ocen jego dostępności i otrzymywania. Spostrzegane wsparcie społeczne jest subiektywną oceną dostępności wsparcia, która wyraża wiarę w to, że jest się kochanym i docenianym przez innych ludzi, na opiekę których można liczyć (Cobb, 1976). Ocena dostępności wsparcia spolecznego może być uznana za cechę osobowości (Pierce, Sarason i Sarason, 1990), gdyż charakteryzuje ją duża stabilność w czasie (Sarason, Sarason i Shearin, 1986). Natomiast otrzymywane wsparcie społeczne ocenia się w odniesieniu do czasu lub konkretnej sytuacji, w której osoba otrzymała pomoc (Sęk i Cieślak, 2004).

Analiza wsparcia społecznego w kontekście stresu skupia się na jego wpływie na redukcję poziomu stresu, a więc na poprawie zdrowia. Jednak zbyt wysoki poziom udzielanego wsparcia społecznego może prowadzić do negatywnych konsekwencji dla jednostki. Takie nadmierne wsparcie odbierane jest jako wynik społecznej presji (Pommersbach, 1988), która może skutkować podwyższeniem stresu, najsilniej u osób z wewnętrznym poczuciem kontroli, dużą potrzebą autonomii i niezależności (Sęk i Cieślak, 2004). 
Pewne cechy osobowości pełnią zatem funkcję moderującą związki wsparcia społecznego i stresu. Z perspektywy założeń zmodyfikowanego przez Sęk (1985) modelu wsparcia Hellera i Swindera, do tych cech można zaliczyć m.in. struktury poznawcze odbiorcy pomocy, wśród których szczególne znaczenie przypisuje się stylom poznawczym, stanowiącym o sposobach przetwarzania informacji i radzenia sobie z zadaniami (Zhang i Sternberg, 2005). Wśród stylów poznawczych największy wpływ na wsparcie społeczne powinien mieć ten, który jest związany z potrzebą autonomii i/lub kompetencjami interpersonalnymi. Obydwa wymogi spełnia wymiar zależności/niezależności od pola, którego powstanie i popularność zawdzięcza się dorobkowi naukowemu Hermana Witkina i jego współpracowników (Matczak, 2006; Bednarek, 2011).

\section{Zależność/niezależność od pola}

W klasycznym ujęciu zależność/niezależność od pola jest uznawana za styl poznawczy, a więc preferowany sposób funkcjonowania poznawczego odpowiadający indywidualnym potrzebom jednostki (Matczak, 2006). Sternberg i Grigorienko (1997) oraz Zhang (2002) zaproponowali podział stylów poznawczych na trzy podstawowe wymiary, a zależność/niezależność od pola przyporządkowali do jednego $\mathrm{z}$ nich, do tak zwanych stylów hemisferycznych. Warto jednak nadmienić, że uznanie zależności/niezależności od pola za styl poznawczy nie jest powszechne. Niektórzy badacze przyjmują, że zależność/niezależność od pola może być jedynie jednym z przejawów ogólnego czynnika inteligencji (Vernon, 1972; Riley i Denmark 1974; por. Richardson i Turner, 2000). Inni dopuszczają uznanie tego wymiaru za zdolność poznawczą (McKenna, 1983 i 1984), percepcyjną (Zhang, 2004) lub przestrzenną (MacLeod, Jackson i Palmer, 1986). Najnowsze badania pokazują silne związki zależności/niezależności od pola z pamięcią roboczą (Bahar i Hansell, 2000; por. Bednarek, 2011), a szczególnie z centralnym systemem wykonawczym i szkicownikiem wzrokowo-przestrzennym (Miyake, Witzki i Emerson, 2001; por. Rittschof, 2010).

Niezależnie od dyskusji o statusie teoretycznym zależności/niezależności od pola uznaje się zgodnie z poglądami Witkina, że zależność od pola determinuje całościową organizację pola, co oznacza, że części składowe pola są odbierane jakby były „zlane” z całością (Witkin, 1968). W miarę wzrastania niezależności od pola jego elementy są spostrzegane jako odrębne wobec zorganizowanego tła (Witkin, 1971). W późniejszych pracach Witkina (Witkin i in., 1979) zakwalifikowano niezależność od pola jako główny przejaw (obok poczucia odrębności ciała i własnej tożsamości jednostki) „rozróżnienia ja od nie-ja”. W tym modelu z zależnością od pola związane były kompetencje interpersonalne, a z niezależnością od pola zdolności do restrukturyzacji pola.

Podstawą dla analizowania związków między wsparciem społecznym a zależnością/niezależnością od pola jest społeczna „odmiennośćc funkcjonowania osób z krańców tej dymensji. Źródłem większych interpersonalnych kompe- 
tencji osób zależnych od pola jest ich mniejsze rozróżnienie „ja” od "nie-ja", a więc mniejsze doświadczanie odrębności od innych (Witkin i Goodenough, 1977b). Prowadzi to do silniejszego odnoszenia się przez osoby zależne od pola do wskaźników zewnętrznych. Widoczne jest to w lepszym zapamiętywaniu przez osoby zależne od pola materiału o charakterze społecznym (Witkin, 1968) oraz w wykorzystywaniu przez nie informacji zwrotnych jako podstawy do budowania samowiedzy (Matczak, 2006).

Z kolei osoby niezależne od pola wykształciły własny, wewnętrzny układ odniesienia, do którego odwołują się także podczas interakcji społecznych (Witkin i Goodenough, 1977b). Odbierają swoje potrzeby, emocje i atrybuty jako odrębne od innych ludzi, dzięki czemu przejawiają większą samoświadomość. Niezależni od pola sprawniej i skuteczniej wpływają na poglądy i zachowania innych ludzi, wobec czego posiadają lepsze kompetencje przywódcze i są bardziej asertywni od zależnych od pola (Matczak, 2006), ale mogą być również odbierani jako bardziej agresywni, niegrzeczni i wymagający (Witkin i Goodenough, 1977b).

Przy rozważaniu wzajemnych relacji między zaleźnościa/niezaleźnością od pola a wsparciem społecznym można uwzględnić to, że osoby zależne od pola mają większą potrzebę poszukiwania pomocy ze strony innych ludzi, która sprzyja ich dużej „społecznej efektywności” (Witkin i Goodenough, 1977b). Dowodzi tego badanie (Mausner i Graham, 1970), w którym osoby zależne od pola $w$ ambiwalentnej sytuacji w większym stopniu niż osoby niezależne poszukiwały informacji $\mathrm{u}$ innych ludzi oraz skuteczniej te informacje wykorzystywaly. Osoby zależne od pola przejawiają także większe zapotrzebowanie, na aprobatę społeczną (Pearson, 1972). Z drugiej strony osoby niezależne od pola w sytuacji stresu kierują się strategiami radzenia sobie opartymi na autonomii i samodzielności (Woodward i Kalyan-Masih, 1990). Ponadto dla potencjalnych relacji zależności/niezależności od pola ze wsparciem społecznym ważne może być to, że większa wrażliwość na innych ludzi osób zależnych od pola rozwija ich większe kompetencje społeczne (Saracho, 2003), co sprawia, że zależni od pola są bardziej popularni wśród rówieśników (Oltman, Goodenough, Witkin, Freedman i Friedman, 1975). Przyczynia się do tego ich „interpersonalna orientacja", która wyraża się dużym zainteresowaniem innymi ludźmi, bliższymi z nimi kontaktami i emocjonalną otwartością (Witkin i Goodenough, 1977b).

\section{Cel badania i hipotezy}

Punktem wyjścia do sformułowania problemów badawczych były doniesienia o odmiennym społecznym funkcjonowaniu osób o różnym stopniu zależności od pola. Na tej podstawie postawiono hipotezę 1, która przewidywała, że istnieją związki między zależnościa/niezależnością od pola a poszczególnymi wymiarami wsparcia społecznego. Zakładano, że osoby zależne od pola spostrzegają większą dostępność wsparcia spolecznego oraz że więcej wsparcia 
społecznego poszukują i otrzymują. Te założenia pozwoliły dodatkowo na sformułowanie przypuszczeń co do tego, że brak zgodności między preferowanym wykorzystywaniem wsparcia społecznego a przejawianym stylem poznawczym będzie skutkował podwyższeniem odczuwanego stresu. Dlatego hipoteza 2 zakłada, że zależność/niezależność od pola wchodzi w interakcje ze spostrzeganym wsparciem społecznym, jego poszukiwaniem i otrzymywaniem dla poziomu odczuwanego stresu.

\section{Metoda}

\section{Narzędzia}

Do diagnozy poziomu stresu wykorzystano Skalę Odczuwanego Stresu (PSS-10), stworzoną przez Cohena, Kamarcka i Mermelsteina (1983), w polskiej adaptacji Juczyńskiego i Ogińskiej-Bulik (2009). PSS-10 składa się z 10 pytań odnoszących się do różnych subiektywnych odczuć, związanych z problemami, zdarzeniami osobistymi, zachowaniami oraz sposobami radzenia sobie. Wszystkie pytania dotyczą oceny natężenia stresu z ostatniego miesiąca. Współczynnik zgodności wewnętrznej alfa Cronbacha wynosi 0,86.

W celu pomiaru wsparcia społecznego użyto Berlińskich Skal Wsparcia Społecznego (BSSS) Schwarzera i Schultza w polskiej adaptacji (Łuszczyńska, Kowalska, Mazurkiewicz i Schwarzer, 2006). BSSS służy do pomiaru poznawczych i behawioralnych wymiarów wsparcia społecznego. Składa się z pięgiła niezależnych skal, z których w badaniu wykorzystano dwie: wsparcie dostępne spostrzegane, wsparcie poszukiwane, aktualne otrzymywane wsparcie. Rzetelność mierzona współczynnikiem alfa Cronbacha dla poszczególnych skal wynosi: spostrzegane wsparcie: 0,88; poszukiwane wsparcie: 0,72; otrzymywane wsparcie: 0,78 .

Do oceny zależności/niezależności od pola wykorzystano Test Ukrytych Figur Witkina w wersji grupowej (The Group Embedded Figures Test - GEFT; Witkin i in., 1971), który badani wykonywali indywidualnie. Osoby badane, rozwiązując test, mają za zadanie znaleźć i oznaczyć proste figury geometryczne, które są ukryte w figurach bardziej złożonych. Osoby, które poprawnie rozwiązują te zadania, mają zdolność do przełamania zastanej struktury i określa się je mianem niezależnych od pola.

Badani po 2-minutowej sesji treningowej przystępowali do badania właściwego, które składało się z dwóch 5-minutowych części, po 9 zadań każda. W całym teście badani mieli wykonać 18 zadań, a końcowy wynik stanowiła liczba poprawnie rozwiązanych zadań w czasie na to przeznaczonym. GEFT nie posiada polskiej adaptacji, dlatego wskaźniki do określenia zależności i niezależności od pola opracowano za pomocą funkcji kategoryzacji wizualnej w programie SPSS. W ten sposób otrzymano trzy równoliczne podgrupy: osób zależnych od pola (od 0 do 7 poprawnie wykonanych zadań), osób o mieszanym stylu 
poznawczym (od 8 do 14 wykonanych zadań) i osób o niezależnym od pola stylu poznawczym (od 15 do 18 wykonanych zadań).

Do powyższych metod dołączono metryczkę (wiek, płeć).

\section{Osoby badane}

Badanie przeprowadzono wśród mieszkańców województw kujawsko-pomorskiego i wielkopolskiego. Uczestniczyło w nim 85 osób $w$ przedziale wiekowym 19-58 lat ( $M=36,4 ; S D=10,66)$, zróżnicowanych pod względem płci (41 kobiet i 44 mężczyzn) i wykształcenia. Wykształcenie podstawowe lub zawodowe posiadało 29,4\% uczestników badania, średnie 27,1\%, wyższe 27,1\%, a $16,5 \%$ badanych było studentami.

\section{Procedura badania}

Udział w badaniu był dobrowolny i anonimowy. Uczestnicy badania zostali zapoznani z celami badania poprzez krótkie ustne wprowadzenie, które w formie pisemnej znajdowało się na pierwszej stronie otrzymanej baterii kwestionariuszy. Badanie rozpoczynało się od indywidualnego testowania za pomocą GEFT, a następnie osoba badana wypełniała pozostałe narzędzia badawcze: Skalę Odczuwanego Stresu (PSS-10), Berlińskie Skale Wsparcia Społecznego (BSSS) oraz metryczkę (wiek, płeć, wykształcenie).

\section{Wyniki}

Sprawdzanie hipotez badawczych rozpoczęto od analizy rozkładów testowanych zmiennych. Test Kołmogorowa-Smirnowa wskazuje, że można przyjąć, że jedynie rozkład wyników poziomu odczuwanego stresu jest normalny $(D(85)=0,06, p<.05)$. Rozkład wyników wsparcia spostrzeganego, poszukiwanego, oczekiwanego oraz zależności/niezależności od pola jest różny od normalnego (dla $d f=85$ i $p<.05$ kolejno: $D_{w s}=0,17 ; D_{w p}=0,1 ; D_{w_{0}}=0,15$; $\left.D_{z / n}=1,2\right)$.

W celu zweryfikowania pierwszej hipotezy badawczej obliczono współczynnik $r$ Spearmana dla związków zależności/niezależności od pola z wymiarami wsparcia. Otrzymane wyniki wskazują, że wraz ze wzrostem niezależności od pola maleje zakres poszukiwania wsparcia społecznego $\left(r_{w p}=0,25\right.$; dla $p<.05)$. Związki zależności/niezależności od pola ze spostrzeganym wsparciem społecznym i jego otrzymywaniem okazały się nieistotne statystycznie na poziomie $p<.05\left(r_{w s}=0,09 ; r_{w o}=-0,12\right)$.

Druga hipoteza badawcza dotyczyła interakcji zależności/niezależności z poszczególnymi wymiarami wsparcia społecznego. W celu zweryfikowania tej hipotezy w pierwszej kolejności zcentrowano każdą z badanych zmiennych poprzez odjęcie średniej zmiennej od każdego otrzymanego dla niej wyniku. 
Iloczyny uzyskanych w ten sposób zmiennych stworzyły testowane interakcje: zależność/niezależność od pola x spostrzegane wsparcie społeczne; zależność/ niezależność od pola x poszukiwane wsparcie społeczne; zależność/niezależność od pola x otrzymywane wsparcie społeczne. Następnie zcentrowane zmienne wprowadzono w pierwszym kroku do modelu regresji hierarchicznej jako efekty główne, by w drugim kroku uwzględnić wspomniane trzy interakcje. Za zmienną zależną uznano poziom odczuwanego stresu.

Tabela 1. Hierarchiczna analiza regresji dla poziomu odczuwanego stresu $(n=85)$

\begin{tabular}{|c|c|c|c|}
\hline & B & Błąd standardowy & $\square$ \\
\hline \multicolumn{4}{|l|}{ Krok 1} \\
\hline Stala & 18,04 & 0,68 & \\
\hline Spostrzegane wsparcie społeczne & $-4,58$ & 1,33 & $-0,38^{* *}$ \\
\hline Poszukiwane wsparcie społeczne & 2,82 & 1,07 & $0,29^{*}$ \\
\hline \multicolumn{4}{|l|}{ Krok 2} \\
\hline Stała & 18,03 & 0,65 & \\
\hline Spostrzegane wsparcie społeczne & $-4,61$ & 1,26 & $-0,38^{* *}$ \\
\hline Poszukiwane wsparcie społeczne & 2,9 & 1,01 & $0,3^{n}$ \\
\hline $\begin{array}{l}\text { Spostrzegane wsparcie społeczne } \mathrm{x} \\
\text { Zależność/niezależność od pola }\end{array}$ & 0,65 & 0,2 & $0,31^{*}$ \\
\hline
\end{tabular}

Otrzymane wyniki zawarte w tabeli 1 pokazują, że spostrzegane wsparcie społeczne $(t(83)=-3,65 ; p<.001)$, poszukiwane wsparcie $(t(83)=2,87$; $p<.01)$ oraz interakcja zależności/niezależności od pola ze spostrzeganym wsparciem społecznym $(t(83)=3,22 ; p<.01$ ) są istotnymi predyktorami poziomu odczuwanego stresu (model, $F(81)=8,581 ; p<.001$ ). Interakcje zależności/ niezależności od pola z poszukiwanym $(t(83)=0,16 ; p>.05)$ i otrzymywanym $(t(83)=0,09 ; p>.05)$ wsparciem społecznym nie zostały uznane za istotne predyktory poziomu stresu. Interakcja zależności/niezależności od pola ze spostrzeganym wsparciem wyjaśnia 9,7\% wariancji poziomu odczuwanego stresu, co stanowi od małej do umiarkowanej wielkości efektu na poziomie $f^{p}=13,3$.

W celu sprawdzenia współliniowości między predyktorami oceniono czynnik inflacji wariancji (VIF) i tolerancję współliniowości (TOL). Problem ze współliniowością występuje, gdy wartości TOL są mniejsze niż 0,2 i/lub VIF większe niż 10 (Field, 2005). Na tej podstawie nie stwierdzono wystąpienia problemów ze współliniowością dla spostrzeganego wsparcia społecznego TOL $=0,85$, VIF $=1,18$, dla poszukiwania wsparcia społecznego $\mathrm{TOL}=0,84$, VIF $=1,18 \mathrm{i}$ dla interakcji spostrzeganego wsparcia z zależnościa/niezależnością od pola, TOL $=0,1, \mathrm{VIF}=1,0$. 
Aby zinterpretować uzyskaną interakcję zależności/niezależności od pola ze spostrzeganym wsparciem społecznym, obliczono linie regresji dla niskiej, średniej i wysokiej niezależności od pola przy niższym, średnim i wyższym poziomie spostrzeganego wsparcia społecznego.

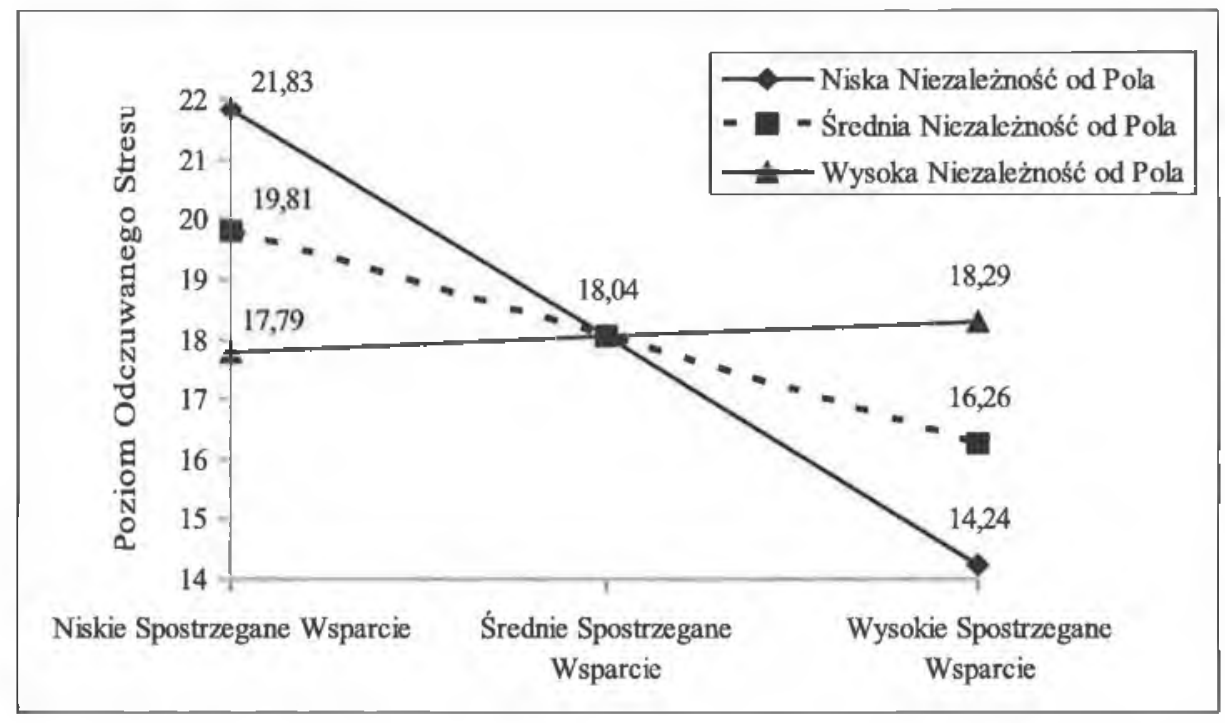

Rycina 1. Wykres prezentujący interakcję zależności/niezależności od pola ze spostrzeganym w\$̣arciem dla poziomu odczuwanego stresu

Jak widać na wykresie, wraz ze wzrostem spostrzeganego wsparcia maleje poziom odczuwanego stresu, przy czym zależność ta nie występuje przy wysokich wartościach niezależności od pola.

\section{Wnioski i dyskusja}

Celem prezentowanego badania była analiza związków między zależnościa/ niezależnością od pola a różnymi wymiarami wsparcia społecznego w kontekście stresu.

W pierwszej hipotezie badawczej założono, że konsekwencją nasilonej "orientacji interpersonalnej" osób zależnych od pola (Witkin i Goodenough, 1977b) będzie większe spostrzeganie dostępności wsparcia społecznego oraz intensywniejsze jego poszukiwanie i otrzymywanie. Wbrew tym pierwotnym przypuszczeniom okazało się, że osoby zależne od pola oceniaja podobnie jak osoby niezależne od pola wielkość posiadanych zasobów społecznych, jak też wielkość otrzymywanego wsparcia. Wykryto jedynie pozytywny związek za- 
leżności od pola z poszukiwaniem wsparcia społecznego. Taki układ wyników można wyjaśnić na dwa sposoby.

Po pierwsze, większe kompetencje społeczne osób zależnych od pola nie są tak oczywiste, jak to utrzymywał Witkin (Witkin i Goodenough, 1977b). W metaanalizie Mckenna (1983) zestawiono 13 badań ekstrawersji oraz zależności od pola i okazało się, że w większości z nich nie zaobserwowano istotnych związków (por. Fineu, 1991). Widiger, Knudson i Rorer (1980) uznali, że wzmożona potrzeba poszukiwania informacji przez osoby zależne od pola nie jest efektem określonego stylu poznawczego, lecz wyrazem braku umiejętności samodzielnego rozwiązywania zadań w ogóle. Co więcej, w badaniu poświęconym poszukiwaniu informacji przez naukowców nie było różnic między osobami zależnymi od pola a niezależnymi w zakresie efektywności komunikacyjnej i skuteczności poszukiwania informacji (Ford, Wilson, Foster, Ellis i Spink, 2002). Uzyskane w badaniach własnych dodatnie korelacje między zależnością od pola i poszukiwaniem wsparcia społecznego oraz zaobserwowany brak związków ze wsparciem spostrzeganym i otrzymywanym wpisują się w powyższe badania.

Drugim sposobem wytłumaczenia braku istotnych związków między zależnością od pola a spostrzeganym i otrzymywanym wsparciem społecznym jest to, że nie uwzględniono strukturalnego aspektu wsparcia, a więc bogactwa sieci kontaktów społecznych osób badanych. Możliwe więc, że „społeczna przewaga” osób zależnych od pola istnieje, ale wyraża się w wyższych wartościach strukturalnego wsparcia, czyli w większej liczbie interakcji społecznych. W trudnych sytuacjach osoby zależne od pola czują się bardziej samotne od niezależnych (Woodward i Kalyan-Masih, 1990). Dlatego też, nawet jeśli zależni od pola posiadają dzięki swoim umiejętnościom społecznym bardziej rozbudowaną sieć znajomych, to jednak z racji ich silnego opierania się na zewnętrznych źródłach odniesienia, ta sieć nie stanowi wystarczającego wsparcia w stosunku do ich potrzeb. Z tego powodu nie uzyskano związku między zależnościa/niezależnością od pola a wsparciem społecznym (subiektywnie) spostrzeganym i otrzymywanym.

Zgodna z tą argumentacją, która opiera się na założeniu, że dla osób zależnych od pola przekonanie o dostępności pomocy innych ludzi ma dużą wagę, jest zaobserwowana w badaniach interakcja zależności/niezależności od pola ze spostrzeganym wsparciem społecznym dla poziomu odczuwanego stresu, która stanowiła jedno z założeń drugiej hipotezy badawczej. Okazało się, że u osób zależnych od pola, które oceniają wsparcie społeczne jako niedostępne, odnotowano największe wartości odczuwanego stresu. Z kolei u osób niezależnych od pola zmiany w zakresie spostrzeganych zasobów społecznych nie przekładają się na zmiany w poziomie odczuwanego stresu. Wytłumaczeniem tego zjawiska może być preferowanie przez osoby niezależne od pola autonomii w działaniu (Witkin i Goodenough, 1977b; Woodward i Kalyan-Masih, 1990), która mogłaby być zagrożona w sytuacji wielu bliskich relacji społecznych. Istnieje wówczas możliwość niedopasowania wsparcia społecznego do potrzeb i preferencji osoby wspieranej (Sęk i Cieślak, 2004). Hipotezę niedopasowania uwia- 
rygodniają wyniki badania (Tsakanikos i Reed, 2003), które pokazują związek niezależności od pola z takimi wymiarami psychotyczności, jak introwertywna anhedonia oraz impulsywny nonkonformizm. Na pierwszą dymensję psychotỵczności składa się m.in. awersja do emocjonalnej i fizycznej intymności oraz brak przyjemności z kontaktów społecznych, a na drugą antysocjalność. U osób niezależnych od pola cechy te moga prowadzić do negatywnych konsekwencji oceny dużej dostępności wsparcia, które niwelują pozytywny wpływ wysokiego poziomu spostrzeganego wsparcia na zmianę poziomu stresu, jaki obserwuje się w ogólnej populacji (Cohen i Wills, 1985).

W ramach drugiej hipotezy badawczej, poza opisaną powyżej wykrytą interakcją, założono wystąpienie interakcji zależności/niezależności od pola z otrzymywanym wsparciem społecznym i z jego poszukiwaniem dla poziomu odczuwanego stresu, co nie zyskało potwierdzenia w uzyskanych wynikach. Brak wystąpienia pierwszej z wymienionych interakcji można uzasadnić tym, że związki między wsparciem otrzymywanym a poziomem stresu moga przyjmować różne kierunki lub w ogóle mogą nie wystąpić (Lindorf, 2000). Natomiast brak interakcji zależności/niezależności od pola z poszukiwaniem wsparcia społecznego prawdopodobnie wynika z tego, że ta strategia radzenia sobie ze stresem jest w sposób intencjonalny regulowana przez jednostkę. Związek między zależnością od pola a poszukiwaniem wsparcia potwierdza to, że podmiot może dostosować zakres poszukiwania wsparcia do własnych preferencji. Z kolei ocena wielkości wsparcia spostrzeganego pozostaje poza kontrolą jednostki, zarówno jeśli uzna się ją za cechę osobowości (Saranson i in., 1990), jak i jako rezulțat kompetencji społecznych (Cohen, Sherrod i Clark, 1986). Dlatego może zaistnieć niedopasowanie spostrzeganego wsparcia z zależnościa/niezależnością od pola, wyrażone pod postacią omawianej wcześniej interakcji.

Ograniczeniem wyników badania jest przekrojowy charakter zebranych danych, z tego powodu nie ma możliwości określenia zależności przyczynowo-skutkowych. Również wielkość badanej próby, biorąc pod uwagę jej heterogeniczność (zróżnicowany wiek, płeć i wykształcenie osób badanych) oraz małe wartości otrzymanych efektów głównych, nakazuje być ostrożnym w formułowanych wnioskach. W celu uwiarygodnienia uzyskanych wyników konieczne są więc dalsze badania na bardziej homogenicznej próbie w modelu eksperymentalnym.

Konkludując, wyniki przedstawionego badania pokazują interesujące relacje między zależnościa/niezależnością od pola a wymiarami wsparcia społecznego w kontekście stresu. Wykryto, że osoby niezależne od pola w mniejszym stopniu poszukują wsparcia społecznego niż zależne od pola, oraz stwierdzono, że u osób niezależnych od pola wysokie wartości spostrzeganego wsparcia nie przekładają się na spadek poziomu stresu, co ma miejsce u osób bardziej zależnych od pola. 


\section{Bibliografia}

Bahar, M. i Hansel, M. H. (2000). The relationship between some psychological factors and their effect on the performance of grid questions and word association tests. Educational Psychology. 20(3). 349-364.

Bednarek, H. (2011). Czy piloci ulegają złudzeniom percepcyjnym? Poznawcze uwarunkowania dezorientacji przestrzennej. Sopot: GWP.

Cobb, S. (1976). Social Support as a Moderator of Life Stress. Psychosomatic Medicine, 38, 300-314.

Cohen, S., Kamarck, T. i Mermelstein, R. (1983). A global measure of perceived stress. Journal of Health and Social Behavior, 24, 385-396.

Cohen, S., Underwood, L. i Gottlieb, B. (red.), (2000). Social support measurement and interventions: A guide for health and social scientists. New York: Oxford University Press.

Cohen, S., Sherrod, D. R. i Clark, M. S. (1986). Social Skills and the Stress-Protective Role of Social Support. Journal of Personality and Social Psychology, 50(5), 963-973.

Cohen, S. i Wills, T. A. (1985). Stress, social support and the buffering hypothesis, Psychological Bulletin, 98, 310-357.

Field, A. (2005). Discovering Statistics Using SPSS. Second Edition. London: SAGE Publications.

Fineu, B. J. (1991). Field-dependence and extraversion: univariate or multivariate research orientation. Perceptual and Motor Skills, 72, 1044-1046.

Frese, M. (1999). Social support as a moderator of the relationship between work stressors and psychological dysfunctioning: A longitudinal study with objective measures. Journal of Occupational Health Psychology, 4(3), 179-192.

Ford, N., Wilson, T. D., Foster, A., Ellis, D. i Spink, A. (2002). Information seeking and mediated searching. Part 4. Cognitive styles in information seeking. Journal of The American Society for Information Science and Technology, 53(9), 728-735.

Juczyński, Z. i Ogińska-Bulik, N. (2009). Narzędzia pomiaru stresu i radzenia sobie ze stresem. Warszawa: Pracownia Testów Psychologicznych.

Kacperczyk, A. (2006). Wsparcie spoleczne w instytucjach opieki paliatywnej i hospicyjnej. łódź: Wydawnictwo Uniwersytetu Łódzkiego.

Lazarus, R. S., DeLongis, A., Folkman, S. i Gruen, R. (1985). Stress and adaptational outcomes: The problem of confounded measures. American Psychologist, 40, 770-779.

Lazarus, R. S. i Folkman, S. (1984). Stress, appraisal, and coping. New York: Springer-Verlag.

Lazarus, R. S. i Folkman, S. (1987). Transactional theory and research on emotions and coping. European Journal of Personality, 1, 141-169.

Lindorf, M. (2000). Is it better to perceive than receive? Social support stress and strain for managers? Psychology, Health \& Medicine, 5(3), 271-286.

Łuszczyńska, A., Kowalska, M., Mazurkiewicz, M. i Schwarzer, R. (2006). Berlińskie Skale Wsparcia Spolecznego (BSSS): Wyniki wstępnych badań nad adaptacją skal i ich własnościami psychometrycznymi. Studia Psychologiczne, 44(3), 17-27.

Łosiak, W. (2008). Psychologia stresu. Warszawa: Wydawnictwo Akademickie i Profesjonalne.

Mausner, B. i Graham, J. (1970). Field dependence and prior reinforcement as determinants of social interaction in judgment. Journal of Personality and Social Psychology, 16(3), 486-493.

Matczak, A. (2006). Style poznawcze. W: J. Strelau (red.), Psychologia. Podręcznik akademicki. T. 2. (s. 761-782). Gdańsk: Gdańskie WYdawnictwo Psychologiczne.

McKenna, F. P. (1983). Field dependence and personality: a re-examination. Social Behavior and Personality, 11(2), 51-55.

McKenna, F. P. (1984). Measures of field dependence: Cognitive style ог cognitive ability? Journal of Personality and Social Psychology, 47(3), 593-603.

MacLeod, C. M., Jackson, R. A. i Palmer, J. (1986). On the relation between spatial ability and field dependence. Intelligence, 10, 141-151. 
Miyake, A., Witzki, A. H. i Emerson, M. J. (2001). Field dependence-independence from a working memory perspective: A dual-task investigation of the Hidden Figures Test. Memory, 9(4/5/6), 445-457.

Oltman, P. K., Goodenough, D. R., Witkin, H. A., Freedman, N. i Friedman, F. (1975). Psychological differentiation as a factor in conflict resolution. Journal of Personality and Social Psychology, 32, 730-736.

Pearson, P. R. (1972). Field dependence and social desirability response set. Journal of Clinical Psychology, 28(2), 166-167.

Pierce, G. R., Sarason, I. G. i Sarason, B. R. (1990). General and relationship-based perceptions of social support: Are two construct better than one? Journal of Personality and Social Psychology, 61, 1028-1039.

Pommersbach, J. (1988). Wsparcie społeczne a choroba. Przegląd Psychologiczny, 31(2), 503-523.

Richardson, J. A. i Turner, T. E. (2000). Field Dependence Revisited I: intelligence. Educational Psychology, 20(3), 255-270.

Riley, R. T. i Denmark, F. L. (1974). Field independence and measures of intelligence: some reconsiderations. Social Behavior and Personality, 2(1), 25-29.

Rittschof, K. A. (2010). Field dependence-independence as visuospatial and executive functioning in working memory: implications for instructional systems design and research. Educational Technology Research and Development, 58(1), 99-114.

Saracho, O. N. (2003). Matching Teachers' and Students' Cognitive Styles. Early Child Development and Care, 173(2-3), 161-173.

Sarason, I. G., Sarason, B. R. i Shearin, E. N. (1986). Social Support as an Individual Difference Variable: Its Stability, Origins, and Relational Aspects. Journal of Personality and Social Psychology, 50(4), 845-855.

Sęk, H. (1985). Wsparcie społeczne - co zrobić, by stało się pojęciem naukowym? Przegląd Psychologiczny, 29(3), 791-800.

Sęk, H. i Cieślak, R. (2004). Wsparcie społeczne - sposoby definiowania, rodzaje i źródła wsparcia. Wybrane koncepcje teoretyczne. W: H. Sęk i R. Cieślak (red.), Wsparcie społeczne, stres i zdrowie (s. 11-29). Warszawa: Wydawnictwo Naukowe PWN.

Sternberg, R. J. i Grigorenko, E. L. (1997). Are cognitive styles still in style? American Psychologist, 52(7), 700-712.

Tsakanikos, E. i Reed, P. (2003). Visuo-spatial processing and dimensions of schizotypy: figure-ground segregation as a function of psychotic-like features. Personality and Individual Differences, 35(3), 703-712.

Vernon, P. E. (1972). The distinctiveness of field independence. Journal of Personality, 4O(3), 346-391.

Widiger, T. A., Knudson, R. M. i Rorer, L.G. (1980). Convergent and discriminant validity of measures of cognitive styles and abilities. Journal of Personality and Social Psychology, 39, 116-129.

Witkin, H. A. (1968). Psychologiczne zróżnicowanie i formy patologii. Przegląd Psychologiczny, $16,75-104$.

Witkin, H. A. i Goodenough, D. R. (1977). Field Dependence and Interpersonal Behavior. Psychological Bulletin, 84(4), 661-689.

Witkin, H. A., Goodenough, D. R. i Karp, S.A. (1967). Stability of cognitive style from childhood to young adulthood. Journal of Personality and Social Psychology, 7(3), 291-300.

Witkin, H. A., Goodenough, D. R. i Oltman, P. K. (1979). Psychological Differentiation: Current Status. Journal of Personality and Social Psychology, 37(7), 1127-1145.

Witkin, H. A., Moore, C. A., Owen, D. R., Raskin, E., Oltman, P. A., Goodenough, R. E. i Friedman, F. (1977). Role of the Field-Dependent and Field-Independent Cognitive Styles in Academic Evolution: A Longitudinal Study. Journal of Educational Psychology, 69(3), 197-211.

Witkin, H. A., Oltman, P. K., Raskin, E. i Karp, S. A. (1971). A Manual for the embedded figures tests. Palo Alto: Consulting Psychologists Press.

Woodward, J. C. i Kalyan-Masih, V. (1990). Violet Loneliness, coping strategies and cognitive styles of the gifted rural adolescent. Adolescence, 25(100), 977-988. 
Zhang, L. F. (2002). Thinking styles: Their relationships with modes of thinking and academic performance. Educational Psychology, 22(3), 331-348.

Zhang, L. F. (2004). Field-dependence/independence: cognitive style or perceptual ability?-validating against thinking styles and academic achievement. Personality \& Individual Differences, 37(6), 1295-1311.

Zhang, L. F. i Sternberg, R. J. (2005). A threefold model of intellectual styles. Educational Psychology Review, 17(1), 1-53.

Dariusz Drazkowski

Lidia Cierpialkowska

Institute of Psychology Adam Mickiewicz University in Poznan

\section{Field dependent/independent and social support in the context of stress}

The aim of this study was to analyze the relationships between field dependence/independence and social support in the context of stress. 85 subjects at the age of $19-58$ years $(M=36,4 ; S D=10.66)$ were examined using Berlin Social Support Scales, Perceived Stress Scale and Group Embedded Figures Test. The results show that field independence is negatively related to seeking social support $(r=0,29)$. There was no relationships between field independence and perceived and received social support. Furthermore, it was detected the interaction field dependence/independence with perceived support for stress $(f 2=13,3)$.

Key words: field dependent/independent, social support, stress, cognitive style 